\title{
Consolata Siniscalco
}

\section{From North to South: a voyage through plant biodiversity in the Italian mountains*}

\begin{abstract}
Siniscalco, C.: From North to South: a voyage through plant biodiversity in the Italian mountains. - Fl. Medit. 29: 181-190. 2019. — ISSN: 1120-4052 printed, 2240-4538 online.

Italy is among the European countries richest in biodiversity, mainly due to a wide variety of geomorphological and climatic conditions. Its very high plant diversity is also the result of its geographical position, acting as a bridge between Central Europe and the Mediterranean Sea and producing the coexistence of different biogeographic elements with a high contingent of endemic plant species, which amounts to more than $15 \%$. As in many other mountains of the world, both the Alps and the Apennines host an extremely rich flora which forms peculiar plant communities characterizing several priority habitats listed in Directive 92/43/EEC and forming wonderful mountain landscapes, where nature and human work merge increasing biodiversity. The voyage from North to South through the Italian mountain plant diversity is an opportunity to observe the responses of plant species and habitats to climate and land use changes that very rapidly are transforming our mountain landscapes, not only at lower altitudes, as expected, but, surprisingly, along the whole altitudinal gradient. Recent results on changes of the summit flora (GLORIA and Summit flora projects), as well as on abandonment of the traditional grazing and forestry activities in some mountain areas and on the spread of nonnative

species, produced significant changes at levels of species, habitat and landscape. On one hand the responses of plants to these changes confirm that they are a threat for plant biodiversity, but on the other hand that plants have a surprisingly rapid capacity to face abrupt climatic or land use variations.
\end{abstract}

Key words: alpine habitats, plant biodiversity, conservation.

Plant biodiversity in Italy is one of the highest of all European countries, both in terms of species richness and of vegetation communities. Knowledge in these two fields is continuously increasing and researches at the national level collect data that are the results of a great number of studies at the regional and local levels.

Examples of these studies at the national level are well represented by the recent checklist of the vascular flora native to Italy (Bartolucci \& al. 2018) and the checklist of the alien flora (Galasso \& al. 2018), both updating the Checklist of the Italian vascular

*Extended and enriched version of the oral presentation given at the International Symposium "Botany at the intersection of Nature, Culture, Art and Science", Selinunte, 28-30 June 2018. 
flora (Conti \& al. 2005), the newly published Flora d'Italia (Pignatti \& al. 2017-19), a paper on endemic plant species (Peruzzi \& al. 2015) and a recent book "Flora in Italia" (Blasi \& Biondi 2017). To all these, and also other publications, a high number of botanists, representing all Italian regions, collaborated in order to provide an accurate analysis of the updated knowledge.

Following the Checklist of the vascular flora native to Italy 8195 taxa occur in our country and 1708 are endemic of one or more regions, highlighting an extraordinary floristic richness, due to the Italian geological, geomorphological, climatic, latitudinal and elevational variability. Some of these features have been studied and their variability has been represented on maps as in the phytoclimatic map of Italy (Blasi \& Michetti 2007) or in the Map of the Important Plant Areas (IPAs) in Italy (Blasi \& al. 2010) and culminated with the Map of vegetational series (Blasi, 2010) that documented the presence of more than 240 vegetational series occurring from North to South and from West to East.

All data agree on the fact that a very high floristic and vegetational richness is located in mountain areas, both in the Alps and in the Apennines, and that rare and endemic species occur mainly in the alpine belt, confirming that mountains are characterized by concentrated geological as well as climatic variability in restricted ranges, following the elevation gradient. For the above mentioned reasons mountains experienced typical climatic histories, in particular during the glacial periods, with an ice cover in some areas, in particular in the Alps and at the higher summits of the Apennines and with the absence of ice cover in other areas. These differences at least partly explain the actual distribution of rare species and, consequently, of rare plant communities.

For these reasons it is highly recommended to explore the Italian mountains, in order to have a look on some of the most interesting areas, taking time for a voyage from the Western Alps to the Southern Apennines, to observe the rich, magnificent flora but also to have a glance on the ecological observations that resulted from the analyses that have been carried out in those places.

Our voyage begins in the Western Alps, and specifically in the Aosta Valley, where the highest summits occur: Monte Bianco (Fig. 1), Monte Rosa, Gran Paradiso, Cervino, all above $4000 \mathrm{~m}$ a.s.1..

In this region the summit alpine flora was studied in the past by several botanists, and in particular by Lino Vaccari, who published his "Flora cacuminale della Valle d'Aosta" (Vaccari 1901) a reliable and complete study on a high number of summits. The re-survey of the same summits studied by Vaccari was carried out by Elena Barni and co-workers in the framework of the Summit Flora Project,

coordinated by Sonia Wipf, working at Davos (Steinbauer \& al. 2018).

In this work the botanists used a dataset of repeated plant surveys from 302 mountain summits across Europe, spanning 145 years of observation, to assess the temporal trajectory of mountain biodiversity changes as a globally coherent imprint of the Anthropocene, and in particular of climate variability. As on the Aosta Valley summits, the authors found a continent-wide acceleration in the rate of increase in plant species richness, with five times as much species enrichment between 2007 and 2016 as fifty years ago, between 1957 and 1966. This acceleration is strikingly synchronized with accelerated global warming and is not linked to alternative global change drivers. The accelerating increases in species richness on mountain summits across this broad spatial extent demonstrate that accelera- 


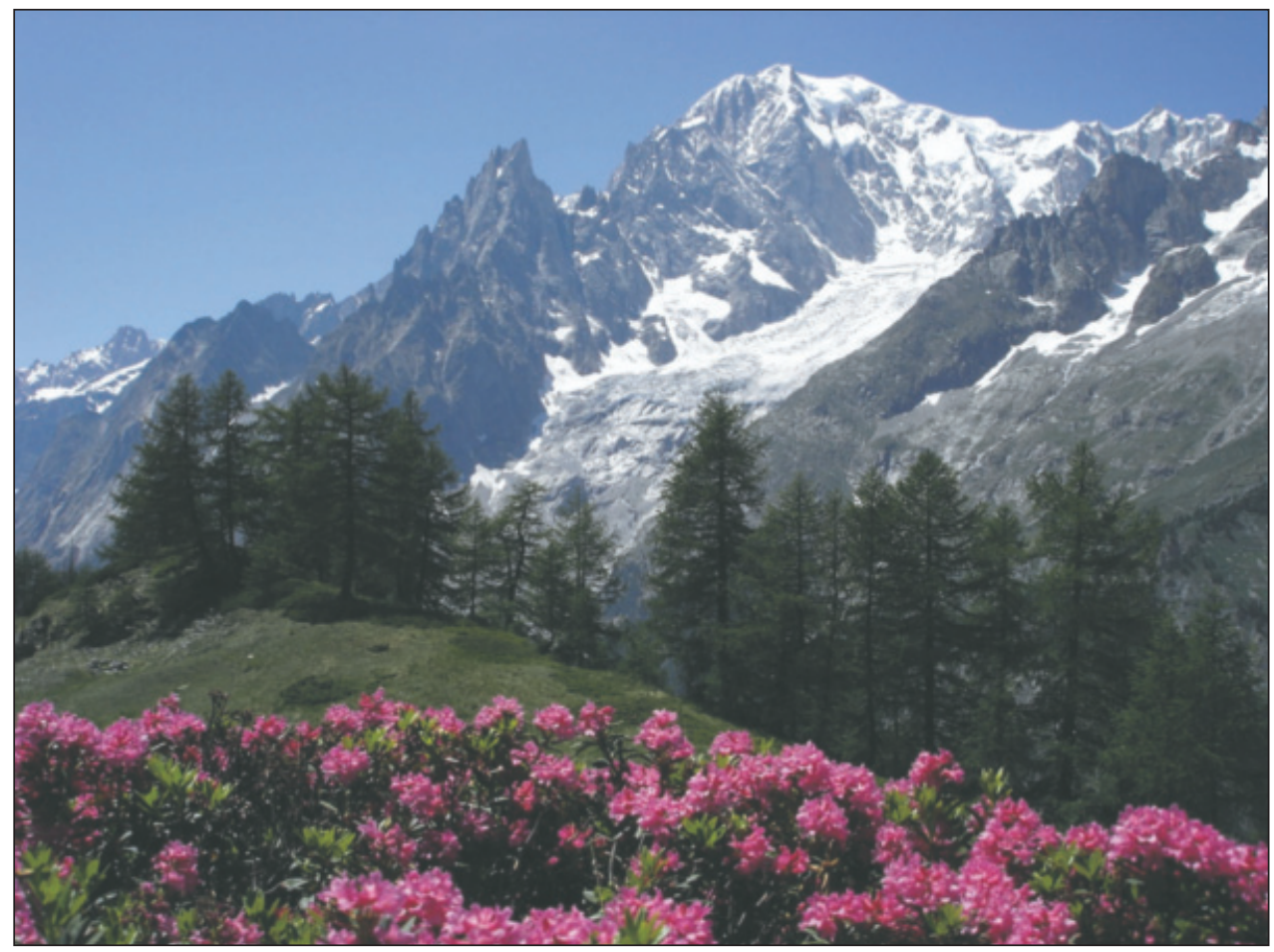

Fig. 1. The Mont Blanc seen from Mont La Saxe (Photo Siniscalco).

tion in climate-induced biotic change is occurring even in remote places on Earth, with potentially far-ranging consequences not only for biodiversity, but also for ecosystem functioning and services.

On ecosystem functioning several studies have been carried out in the Aosta Valley to highlight how subalpine grasslands react to the summer heat wave that more and more often occurs during August: the dry grassland vegetation, and in particular dry grasses as Nardus stricta L. stop their activity and only after the first rainfalls, at the end of August, become green and active, while forbs as Trifolium alpinum L., Arnica montana L., and Geum montanum L. continue to carry out their activity even under very dry summer conditions (Cremonese \& al. 2017). Climate change causes very clear responses on the grassland community, even when snow melt begins earlier than usual in April or May because without snow the soil and plant temperature can be several degrees under zero, causing damages to the plants.

One important point in these studies is that we have to concentrate on the community but also on the single species response, trying to analyse the plant traits, in order to understand their ecological needs and to predict which will be their response to interannual climate variability.

Moving on to South, we stop in Valle di Susa, one of the most interesting endo-alpine valleys because, if compared to the others, as Engadin and Valais in Switzerland, Val 
Venosta and Valle d'Aosta, its flora is enriched by several Mediterranean species, in particular in the driest areas, located in the middle of the Valley. This confirms what was observed by Aeschimann (Aeschimann \& al. 2004): the richest flora in alpine areas is located where, in addition to the typical species, ranging on the chain, Mediterranean species arrived in the past, in warmer periods.

In the Xero-thermic oasis South facing slopes (SIC IT1110030 "Oasi xerotermiche della Valle di Susa - Orrido di Chianocco e Foresto) the very dry climate, less than $600 \mathrm{~mm}$ yearly precipitations, with strong winds blowing everyday, justify the occurrence of two priority habitats included in the Directive 92/43/EEC (Habitat Directive), "Dry semi natural grasslands (Festuco-Brometalia)-important orchid rich sites" (6210*), and the "Steppic, sub-pannonian grasslands" $\left(6240^{*}\right)$. Both grasslands need grazing to be maintained, so that a Life Project was carried out (Life 12NAT/IT/000818 Xero-Grazing) for the Semi-natural dry-grassland conservation and restoration in Valle Susa through grazing management.

The most wide spread Mediterranean species are Euphorbia sulcata Lens, Asterolinon linum-stellatum (L.) Duby, Linum strictum L., Ononis reclinata L., Leuzea conifera (L.) DC., Crupina vulgaris Cass., Linum suffruticosum L., Lavandula angustifolia Mill., Helianthemum apenninum (L.) Mill., Ononis minutissima L., Coronilla minima L., and Juniperus oxycedrus L. (Fig. 2). Moreover, 29 orchid species occur in the dry grasslands, e.g. Ophris fuciflora (F.W. Schmidt) Moench, Ophrys tetraloniae W. P. Teschner, Neotinea tridentata (Scop.) R. M. Bateman, Pridgeon \& M.W. Chase, Neotinea ustulata (L.) R.M. Bateman, Pridgeon \& M.W. Chase, Anacamptis pyramidalis (L.) Rich., Epipactis atrorubens (Hoffm.) Besser, Cephalanthera longifolia (L.) Fritsch and Cephalanthera rubra (L.) Rich. In the steppic, sub-pannonian grasslands, which have been observed for the first time in such Western alpine areas and were not expected to occur outside their typical range, Stipa pennata L. and Cleistogenes serotina (L.) Keng characterize physionomically the grasslands, and are to be referred to the alliance Stipo-Poion carniolicae.

This area is very interesting to visit, being an island of Mediterranean vegetation in the middle of the Alps.

Moving South in our voyage, we arrive in the Maritime Alps, one of most interesting hot spots of the Italian flora, where the influence of the Mediterranean sea avoided the presence of a continuous ice cover during the Quaternary glaciations and the formation of neoendemic species, after this period. This uncommon conditions in an area of the Alps, justifies the actual occurrence of several rare, endemic species (Fig. 3) as for example Saxifraga florulenta Moretti, Saxifraga lingulata Bellardi, Primula allionii Loisel, Viola valderia All., Campanula alpestris All. and Fritillaria tubaeformis subsp. moggridgei (Boiss. \& Reuter ex Planch.) Rix. All these species are typical of rocky slopes or of alpine grasslands, where competition with other species is low. The researches on these and of other species allow confirming the historical, geomorphological and genetic reasons of their survival or their more recent formation in this very interesting area of the Alps.

Moving once more to South, and having an interest on the previously cited topics linked to the history of the Italian mountain flora, we arrive to the Gran Sasso and Majella groups.

The secondary prairies with dominant Bromus erectus Huds. are quite similar to the ones that we saw in Susa Valley, with Helianthemum apenninum (L.) Mill., Medicago minima (L.) L., Neotinea ustulata (L.) R.M. Bateman, Pridgeon \& M.W. Chase, Anacamptis 


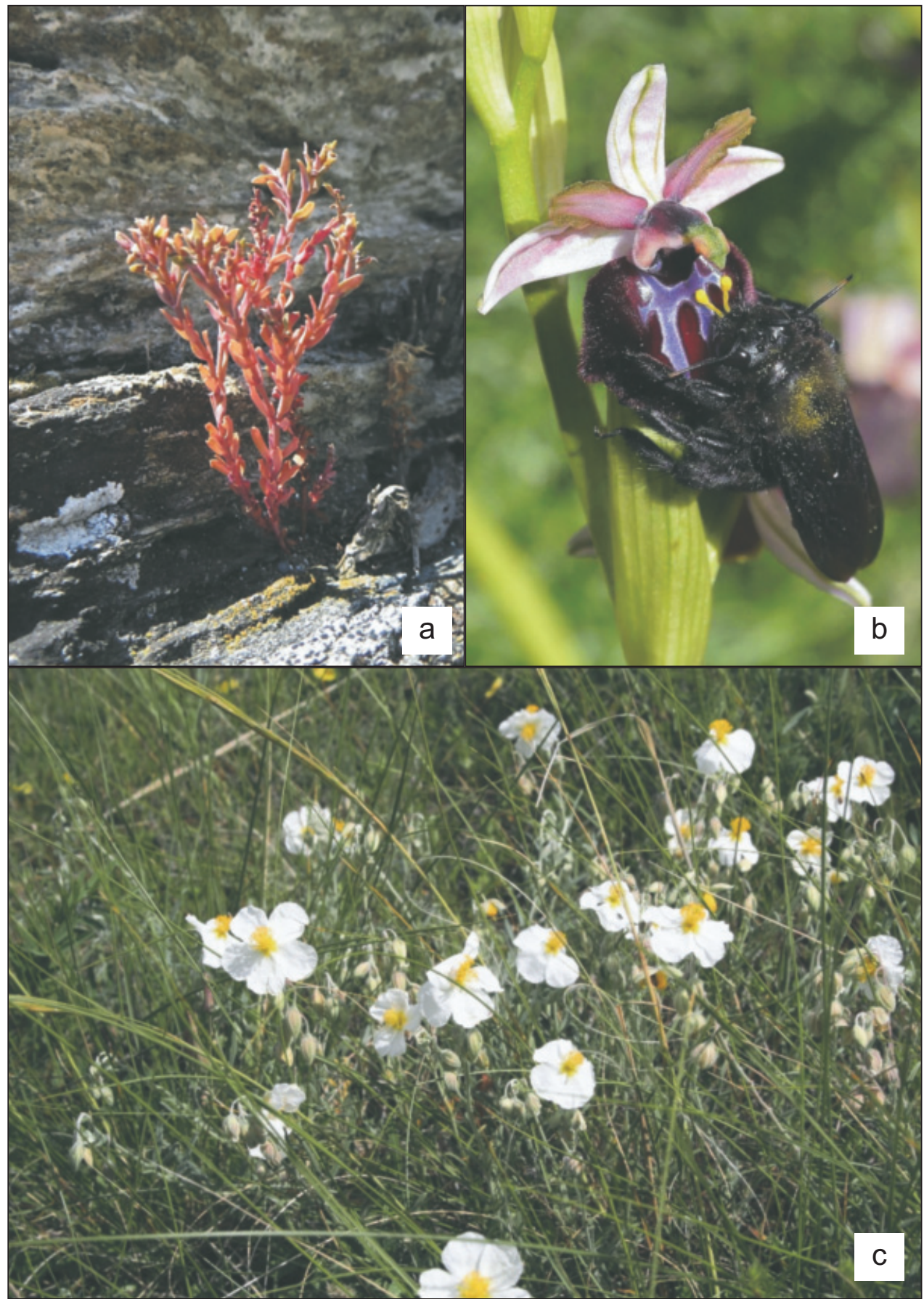

Fig. 2. a) Euphorbia sulcata in Susa Valley dry grasslands (Photo Gorlier); b) Ophys fuciflora in the Susa Valley dry grasslands (Photo Davì); c) Helianthemum apenninum (Photo Gorlier). 


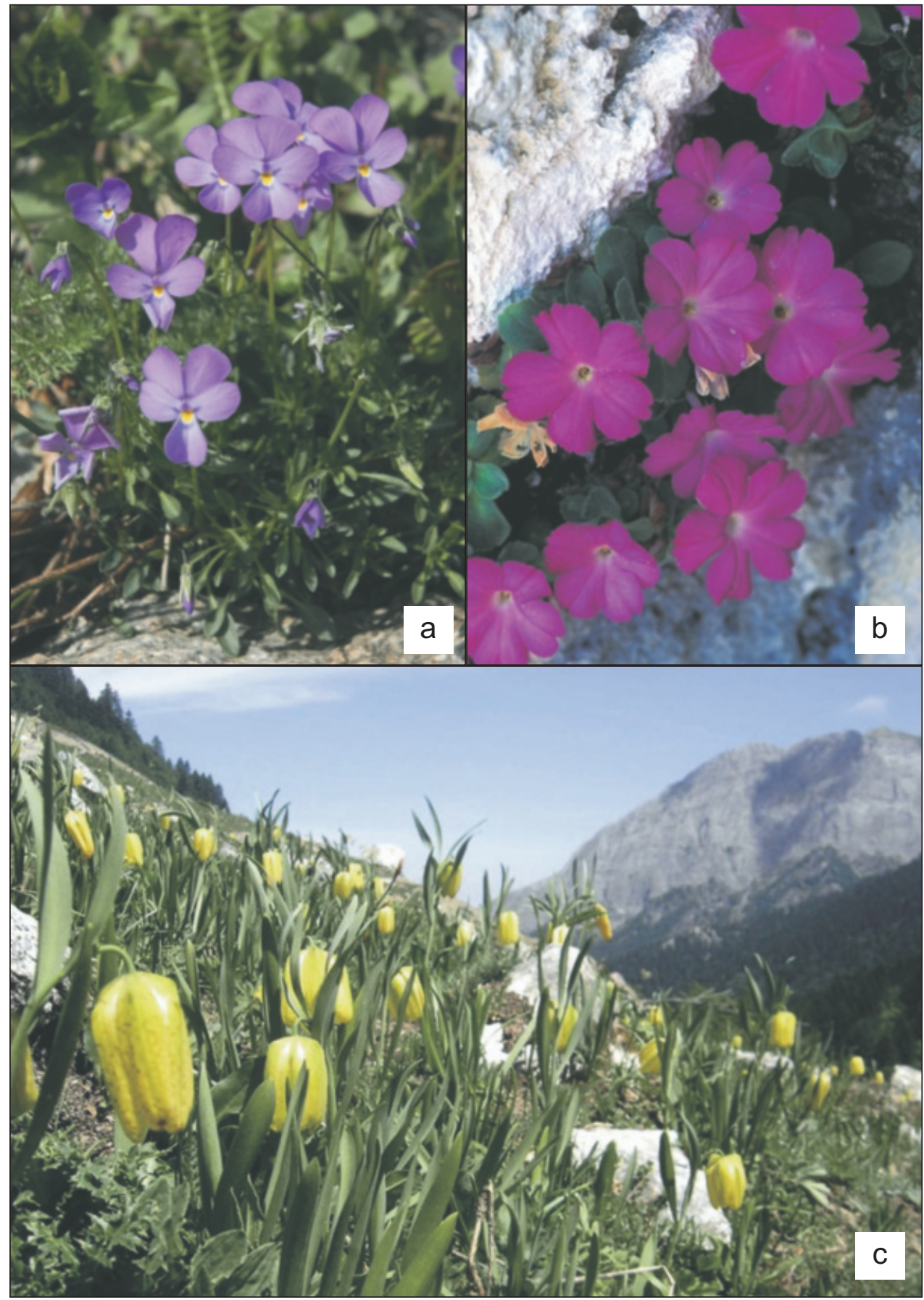

Fig. 3. a) Viola valderia and b) Primula allionii in the Maritime Alps (Photo Masante); Fritillaria tubaeformis subsp. moggridgei in the Maritime Alps (Photo Mucciarelli) 


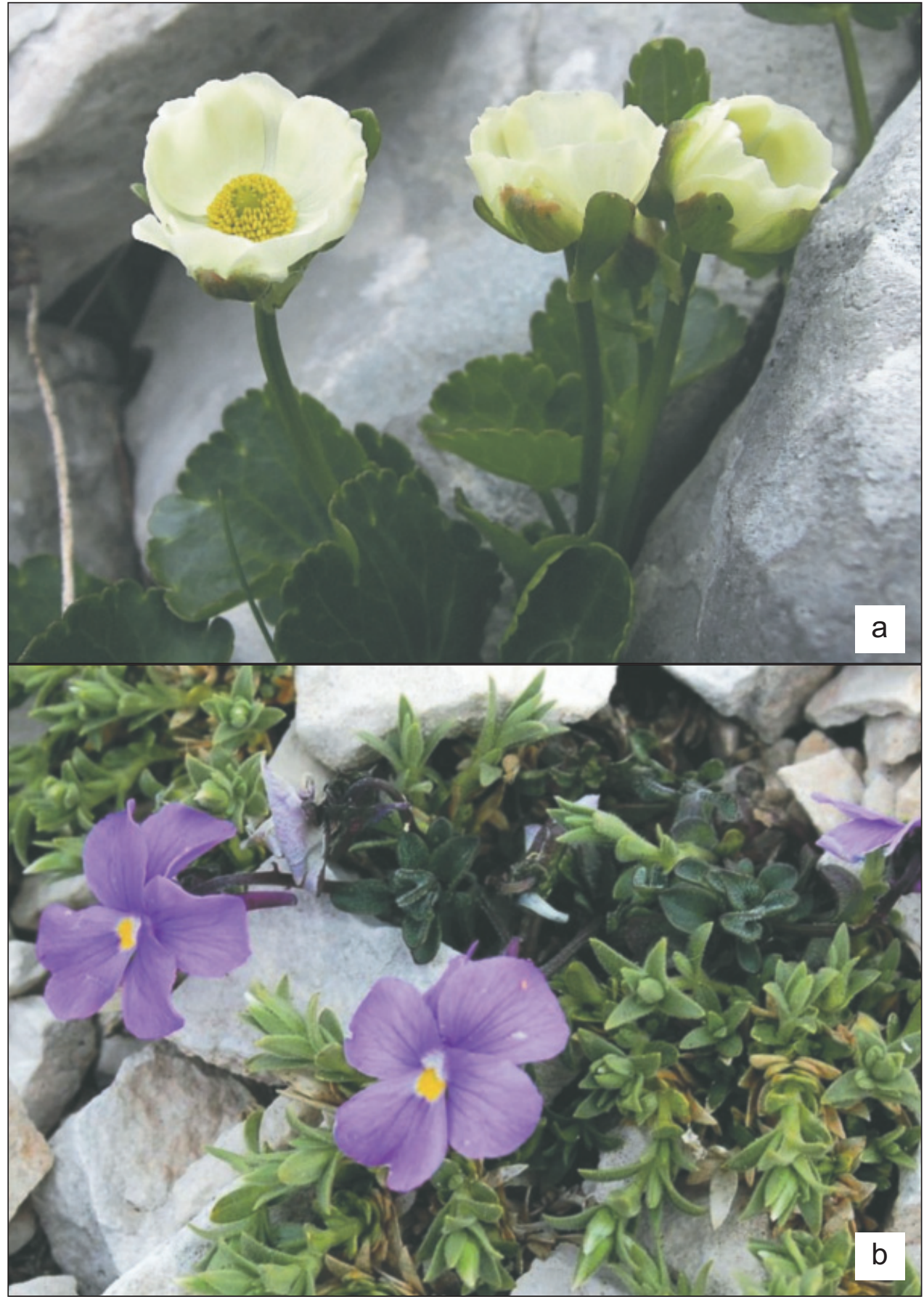

Fig. 4. a) Ranunculus magellensis in Majella (Photo Nicolella); b) Fig. 13. Viola magellensis in Majella (Photo Nicolella). 


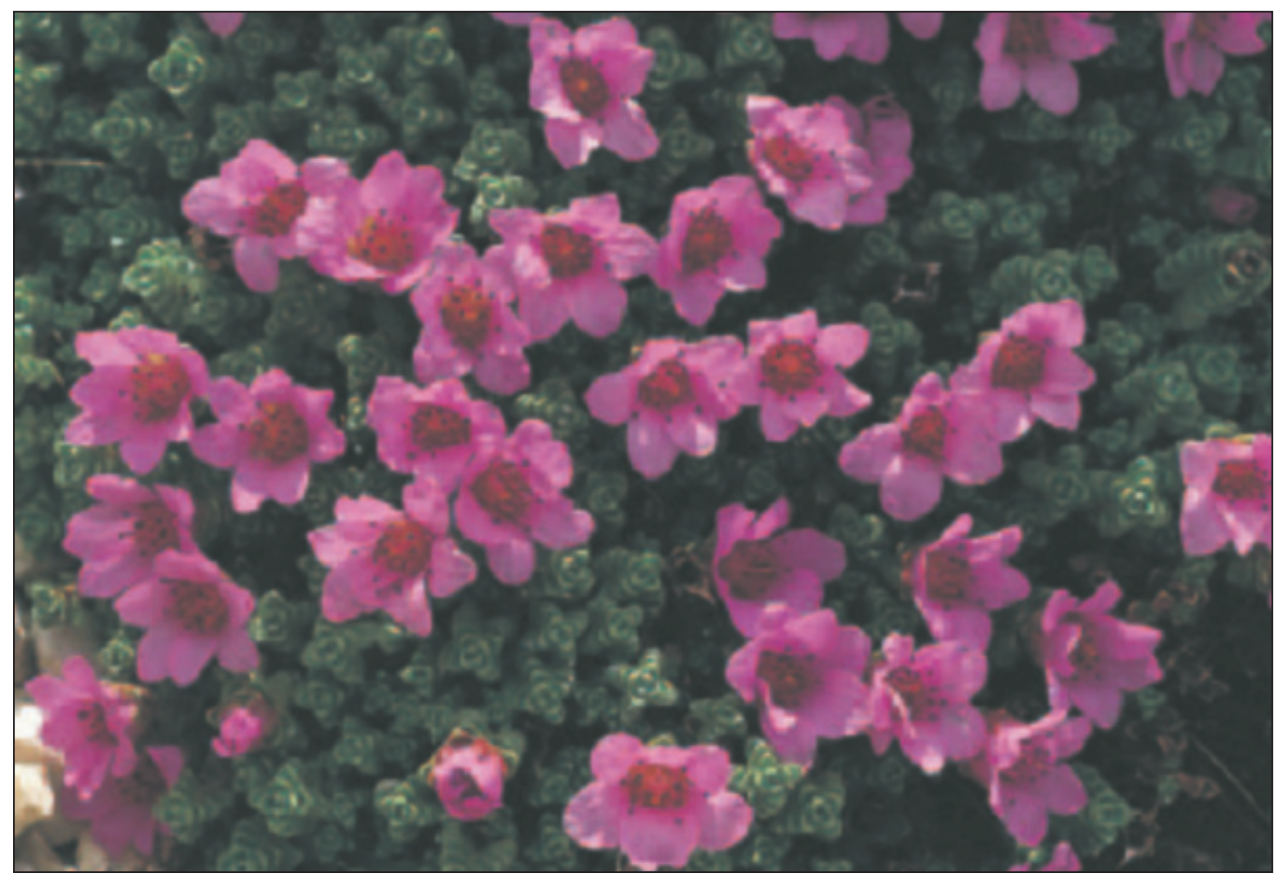

Fig. 5. Saxifraga oppositifolia subsp. speciosa (Photo Pirone).

pyramidalis (L.) Rich. and other species that very interestingly vicariate the Susa Valley ones, as Eryngium amethystinum L. at the place on Eryngium campestre L., Trinia dalechampii (Ten.) Janch. at the place of Trinia glauca (L.) Dumort.

When we arrive to the highest elevations, above the timberline, it is possible to see a magnificent flora, characterized by an extraordinary high biodiversity described by Pirone (2006) and Pirone and Frattaroli (2011). Migration, mainly from North and East, and speciation processes lead to a very rich floristic diversity that includes, beyond endemic species, a relevant number of relict species, similarly to what we have seen in the Maritime Alps. These species have wonderful flowers that evolved to respond to the scarce number and variety of pollinator insects at those elevations. An analytical analysis of these species is reported in Blasi and Biondi (2017), with notes on distribution, habitats and conservation, as for Ranunculus magellensis Ten., Viola magellensis Porta \& Rigo, Saxifraga oppositifolia subsp. speciosa (Dörfl. \& Hayek) Engl. \& Irmsch. and Androsace mathildae Levier (Figs. 4-5). This last species is listed in the Habitat Directive and in Abruzzo Red List, as many other species of the high elevation habitats of Gran Sasso and Majella.

This virtual voyage that brought us to visit examples of some of the most interesting Italian mountain systems is an invitation to go and visit them on the field. These excursions confirms the extraordinary high biodiversity of the mountain flora also in terms of biogeographical as well as evolutionary value. On these bases the need is confirmed to monitor 
the presence and conservation status of these species and vegetation communities in the future, in order to control the effects of climate and eventually land use changes on their survival and functionality.

\section{Acknowledgements}

I want to thank Carlo Blasi, professor at Sapienza Università di Roma and past President of Società Botanica Italiana, for all his work on flora and vegetation in Italy, that he coordinated and continues to coordinate collaborating with many Italian botanists, specialists on their specific regions. His farsighted and tireless work allowed to gather the huge amount of single researches that were carried out in many years of field and laboratory works in the Italian institutions, leaving a precious legacy in several papers and books which I cited here only in a very low number, due to the limited aims and space of this work that I presented at the Congress of Selinunte.

I want to thank also professor Franco Raimondo for having organized this very interesting and various Congress in the wonderful Selinunte.

\section{References}

Aeschimann, D., Lauber, K., Moser, D. M. \& Theurillat, J. P. 2004: Flora alpina, 3. - Bologna. Bartolucci, F., Peruzzi, L., Galasso, G., Albano, A., Alessandrini A., Ardenghi, N.M.G., Astuti, G., Bacchetta, G., Ballelli, S., Banfi, E., Barberis, G., Bernardo, L., Bouvet, D., Bovio, M., Cecchi, L., Di Pietro, R., Domina, G., Fascetti, S., Fenu, G., Festi, F., Foggi, B., Gallo, L., Gottschlich, G., Gubellini, L., Iamonico, D., Iberite, M., Jiménez-Mejías, P., Lattanzi, E., Marchetti, D., Martinetto, E., Masin, R. R., Medagli, P., Passalacqua, N.G., Peccennini, S., Pennesi, R., Pierini, B., Poldini, L., Prosser, F., Raimondo, F. M., Roma-Marzio, F., Rosati, L., Santangelo, A., Scoppola, A., Scortegagna, S., Selvaggi, A., Selvi, F., Soldano, A., Stinca, A., Wagensommer, R. P., Wilhalm, T. \& Conti, F. 2018: An updated checklist of the vascular flora native to Italy. - Pl. Biosyst. 152(2): 179-303. https://doi.org/ 10.1080/11263504.2017.1419996

Blasi, C. (ed.) 2010: La Vegetazione d'Italia con Carta delle Serie di Vegetazione in scala 1: 500000. - Roma.

— \& Biondi, E. 2017: La flora in Italia. - Roma.

— \& Michetti, L. 2007: The climate of Italy. - Pp. 57-66 in: Blasi, C., Boitani, L., La Posta, S., Manes, F. \& Marchetti, M. (eds), Biodiversity in Italy. - Rome.

—, Marignani, M., Copiz, R., Fipaldini, M. \& Del Vico, E. (eds) 2010: Le Aree Importanti per le Piante nelle Regioni d'Italia: il presente e il futuro della conservazione del nostro patrimonio botanico. - Roma.

Conti, F., Abbate, G., Alessandrini, A. \& Blasi C. (eds) 2005: An annotated checklist of the Italian vascular flora. - Roma.

Cremonese, E., Filippa, G., Galvagno, M., Siniscalco, C., Oddi, L., Morra di Cella, U. \& Migliavacca, M. 2017: Heat wave hinders green wave: The impact of climate extreme on the phenology of a mountain grassland. - Agric. Forest Meteorol. 247: 320-330. https://doi.org/10.1016/j.agrformet.2017.08.016

Galasso, G, Conti, F., Peruzzi, L., Ardenghi, N. M. G., Banfi, E., Celesti-Grapow, L., Albano, A., Alessandrini, A., Bacchetta, G., Ballelli, S., Bandini Mazzanti, M., Barberis, G., Bernardo, L., Blasi, C., Bouvet, D., Bovio, M., Cecchi, L., Del Guacchio, E., Domina, G., Fascetti, S., Gallo, L., Gubellini, L., Guiggi, A., Iamonico, D., Iberite, M., Jiménez-Mejías, P., Lattanzi, E., Marchetti, D., Martinetto, E., Masin, R.R., Medagli, P., Passalacqua, N. G., Peccenini, S., 
Pennei, R., Pierini, B., Podda, L., Poldini, L., Prosser, F., Raimondo, F. M., Roma-Marzio, F., Rosati, L., Santangelo, A., Scoppola, A., Scortegagna, S., Selvaggi, A., Selvi, F., Soldano, A., Stinca, A., Wagensommer, R. P., Wilhalm, T. \& Bartolucci, F. 2018: An updated checklist of the vascular flora alien to Italy. - Pl. Biosyst. 152(3): 556-592. http://doi.org/ 10.1080/11263504.2018.1441197

Peruzzi, L., Domina, G., Bartolucci, F., Galasso, G., Peccenini, S., Raimondo, F. M., Albano, A., Alessandrini, A., Banfi, E., Barberis, G., Bernardo, L., Bovio, M., Brullo, S., Brundu, G., Brunu, A., Camarda, I., Carta, L., Conti, F., Croce, A., Iamonico, D., Iberite, M., Iiriti, G., Longo, D., Marsili, S., Medagli, P., Pistarino, A., Salmeri, C., Santangelo, A., Scassellati, E., Selvi, F., Soldano, A., Stinca, A., Villani, M., Wagensommer, R. P. \& Passalacqua, N. G. 2015: An inventory of the names of vascular plants endemic to Italy, their loci classici and types. Phytotaxa 196(1): 1-217. https://doi.org/10.11646/phytotaxa.196.1.1

Pignatti, S., Guarino, R. \& La Rosa, M. 2017-2019: Flora d'Italia, $2^{\circ}$ edizione e Flora digitale. Milano.

Pirone, G. 2006. La biodiversità vegetale in Abruzzo: stato delle conoscenze. - Pp. 19-36 in: Di Cecco, M. \& Andrisano, T. (eds), La biodiversità vegetale nelle aree protette in Abruzzo: studi es esperienze a confronto. Documenti tecnico-scientifici del parco Nazionale della Majella, 3. - Guardiagrele

Pirone, G. \& Frattaroli, A. R. 2011: Lineamenti della biodiversità vegetale in Abruzzo. - Acta Italus Hortus 1: 9-12.

Steinbauer, M. J., Grytnes, J.-A, Jurasinski, G., Kulonen, A., Lenoir, J., Pauli, H., Rixen, C., Winkler, M., Bardy-Durchhalter, M., Barni, E., Bjorkman, A. D., Breiner, F. T., Burg, S., Czortek, P., Dawes, M. A., Delimat, A., Dullinger, S., Erschbamer, B., Felde, V. A., Fernández-Arberas, O., Fossheim, K. F., Gómez-García, D., Georges, D., Grindrud, E. T., Haider, S., Haugum, S. V., Henriksen, H., Herreros, M. J., Jaroszewicz, B., Jaroszynska, F., Kanka, R., Kapfer, J., Klanderud, K., Kühn, I., Lamprecht, A., Matteodo, M., di Cella, U. M., Normand, S., Odland, A., Olsen, S. L., Palacio, S., Petey, M., Piscová, V., Sedlakova, B., Steinbauer, K., Stöckli, V., Svenning, J.-C., Teppa, G., Theurillat, J.-P., Vittoz, P., Woodin, Sarah J. \& Zimmermann, N. E. 2018: Accelerated increase in plant species richness on mountain summits is linked to warming. - Nature 556: 231-234. https://doi.org/10.1038/s41586-018-0005-6

Vaccari, L. 1901: Flora cacuminale della Valle d'Aosta. - Nuovo Giorn. Bot. Ital., n.s., 8: 416-439, 527-542.

Address of the author:

Consolata Siniscalco,

Department of Life Science and Systems Biology, University of Torino, Italy. Viale Mattioli, 25. 10125 Torino, Italy. E-mail: consolata.siniscalco@unito.it 